\title{
ZANIKLÝ MEANDR U SEVERNÍHO PŘEDHRADÍ ARCHEOLOGICKÉ LOKALITY POHANSKO U BŘECLAVI
}

\author{
Paleomeander at the Northern bailey of the archaeological site Pohansko near Břeclav \\ Jan Petř́ík', Nela Doláková1 $₫$, Slavomír Nehyba', Zuzana Lend’ákováa , Michaela Prištáková2, \\ Katarína Adameková1, Libor Petr ${ }^{4}$, Petr Dresler², Jiři Macháček ${ }^{2}$ \\ 'Ústav geologických věd PřF, MU, Kotlářská 2, 61137 Brno \\ 2 Ústav archeologie a muzeologie FF, MU Brno, Arna Nováka 1/1, 60200 Brno \\ ${ }^{3}$ Katedra geologie PřF UP Olomouc, 17. listopadu1192/12, Olomouc \\ ${ }^{4}$ Ústav botaniky a zoologie PřF MU Brno, Kamenice 753/5, 62500 Brno
}

Key words: Pohansko near Břeclav, Holocene, floodplain, sedimentary, geophysiscs, palynology

\begin{abstract}
The site is situated in the bottomland near the confluence of Dyje and Morava rivers. The junction area is split by many sides and inactive channels. The human impact (settlement establishment, deforestation and landscape management) is also reflected in the bottomland development. Processes lead to erosion, accumulation of sediments in river beds and changes in vegetation. One of the peaks of the settlement of the studied area can be considered during existence of the Great Moravian Empire when the settlement agglomerations developed directly in the floodplain. The area has been intensively archaeologically studied for a long time. In the context of the ongoing climate change and increasing intensity of floods the relationship between climate, natural conditions and the functioning of the human settlements comes to the forefront of scientific interest. For the reconstruction of the complicated floodplain development a combination of different research methods was used. For direct determination of stratigraphy an excavated transect through the sediments connecting the edge of the settlement (in the area of the so called Northern bailey) on the sand elevation (,hrúd“) and lower flood-plain step in the area of presumptive paleomeander has been studied. Direct field documentation and palynological and sedimentological studies and ${ }^{14} \mathrm{C}$ dating method were utilized. These methods have been supplemented by remote sensing methods: Geophysics (ERT, DEMP), Lidar. On their basis a digital relief model (extend of measured area was $54000 \mathrm{~m}^{2}$ ) was created as well as a map of conductivity anomalies. The study documented a sequence of extinct riverbeds (a series of fluvial point bars) of various ages at the northern edge of Pohansko. Their stratigraphic position proves the stage when the active channel was eroding the edge of the archaeological site. The sediments stored in previous periods were destroyed by erosion in this space. The aggradation of the floodplain occurred in $14^{\text {th }}-16^{\text {th }}$ century. Results of pollen analysis indicate the presence of a mosaic of forested and open landscape of mesophilous alluvial woodlands and open areas. The immediate vicinity of the sedimentary area was not too much affected by agricultural activity at that time. Compared to palynospectra from sediments of the Great Moravian settlement, the deforestation intensity and the proportion of anthropogenic indicators were noticeably lower.
\end{abstract}

\section{Úvod}

Niva řeky reaguje citlivým způsobem na změny klimatu, lidské zásahy do krajiny, a s tím spojené změny vegetačního krytu a svahové procesy. To vše ovlivňuje průtok a množství unášeného materiálu, jejichž odrazem je poměr mezi agradací a erozí, tedy i fluviální geomorfologie a sedimentologie. Tato multikauzalita způsobuje, že vývoj nivy není lineární a rychlost odezvy na změny se prodlužuje u větších toků. $V$ případě velkých řek trvá $v$ př́ípadě změn desítky až stovky let, než je dosaženo opětovné rovnováhy (Castelltort, Van den Driessche 2003).

V posledních několika tisíciletích je středoevropská krajina stále markantněji ovlivňována lidskými aktivitami a to se odráží také ve vývoji řiční nivy. Člověk od pravěku odlesňuje a obhospodařuje krajinu a zároveň zakládá i svá sídla, která jsou závislá na zdrojích vody. Tyto změny se $\mathrm{v}$ různé podobě odrážejí $\mathrm{v}$ pylových spektrech $\mathrm{v}$ závislosti na intenzitě lidských aktivit a populační hustotě, kdy narůstá podíl synantropní vegetace a mění se skladba dřevin. Odlesnění krajiny, zakládání polí a pastva vedou

$\square$ nela@sci.muni.cz

DOI: https://doi.org/10.5817/GVMS2018-1-2-41 ke spuštění eroze a to se odráží v akumulaci sedimentů v ř́ićních nivách (Boardman, Bell 1992; Rulf 1994; Enters et al. 2008; Petřík et al. 2015) a změnách vegetace (Opravil 1983; Petř́ík et al. 2015).

Osídlení aluviálních oblastí v minulosti bylo proměnlivé a za jeden $\mathrm{z}$ jeho vrcholů můžeme pokládat období existence Velkomoravské říše, kdy došlo k rozvoji sídelních aglomerací prímo v nivě. Toto relativně intenzivní osídlení mělo rozsáhlé hospodářské zázemí, které využívalo vodní toky například k dálkovému transportu kamenných surovin. Raně středověké aglomerace z období Velké Moravy situované v nivě byly intenzivně archeologicky zkoumány (např. Pohansko, Mikulčice; Mazuch 2012). Tamější unikátní archeologické situace byly jen okrajově interpretovány v kontextu př́rodního prostředí (Opravil 1983; Macháček et al. 2007; Doláková et al. 2010). Bez znalostí vývoje nivního prostředí nelze interpretovat změny osídlení a zánik aglomerací, protože ten může souviset s řadou environmentálních i sociálních změn. $V$ souvislosti s probíhajícími klimatickými změnami a zvyšující se intenzitou povodní se do popředí zájmu archeologie dostává problematika vztahu mezi klimatem, př́rodními podmínkami a fungováním lidských sídel 
(Kalicki 2006; Starkel et al. 2007; Schneeweiss, Schatz 2014).

Důležitým zdrojem paleoekologických informací o těchto procesech jsou nivní sedimenty větších toků. $\mathrm{V}$ tomto čtecím rámci je možné sledovat historii lidského osídlení a využití krajiny v archeologickém a paleoekologickém záznamu. Při řešení daného problému může být využit multiproxy př́stup, kdy jsou kombinovány biologické proxy s fyzikálními analýzami sedimentů a archeologickým výzkumem. V tomto duchu byla zkoumána soustava zaniklých meandrů u sv. předhradí na archeologické lokalitě Pohansko u Břeclavi. Dílčím cílem je geomorfologická a sedimentologická charakteristika nivy v sousedství archeologické lokality. To umožní následné zjištění prostorového i časového vztahu archeologických situací i konkrétních fluviálních tvarů a sedimentů. Vhodné sedimenty navíc poskytnou informace o intenzitě a lidském vlivu na krajinu v zachyceném paleoekologickém záznamu.

Za účelem řešení dané problematiky byl na lokalitě otevřen transekt sedimenty, spojující okraj sídliště (v prostoru tzv. Severního předhradí) na písečné elevaci (tzv. hrúdu) a nižší nivní stupeň v prostoru předpokládaného paleomeandru.

\section{Geologické poměry a paleoekologie}

Studovaná oblast je situována na dolním toku Dyje (Dyjsko-svratecký úval), jejiž povodí zaujímá jihovýchodní část České republiky při hranici s Rakouskem. Při soutoku s řekou Moravou je niva Dyje široká $3-8 \mathrm{~km}$ a je rozčleněna mnoha bočními a neaktivními kanály. Současný průměrný průtok je $41,70 \mathrm{~m}^{3} / \mathrm{s}$ při sklonu $0,0032 \mathrm{~m} /$ $\mathrm{km}$, což odpovídá meandrujícím tokům (Leopold, Wolman 1957). Zkoumaný prostor se nachází při severním okraji písčité vyvýšeniny (hrúd) u tzv. severovýchodního předhradí velkomoravského centra Pohansko u Břeclavi (Dresler, Macháček 2008). Současný porost je zde tvořen loukami a lužním lesem s dominujícími dřevinami Quercus, Tilia a Ulmus (Roleček et al. 2015). Bažinná vegetace je př́tomna v okolí mnoha zaniklých ř́ičních ramen. Niva zde byla využita jako lovecká obora (Miklín, Hradecký 2016), takže změny ve využití krajiny byly za posledních 200 let relativně malé. Navíc byl prostor $v$ době po druhé světové válce součástí železné opony, takže vstup do oblasti byl omezen.

Předpokládá se, že těleso tzv. hrúdu je zbytkem pozdně glaciální nivy s meandrující řekou, které bylo erodováno na konci glaciálu a v časném holocénu (Havliček et al. 2016). Na základě přitomnosti mezolitických artefaktů a subfosilních půd lze ovšem usuzovat na velmi komplikovanou genezi celého tělesa, která nejspíše zahrnovala fluviální i eolickou resedimentaci s pedogenezí v klidných fázích (Havlíček, Smolíková 2002). Vrtné práce v okolí Pohanska jsou sumarizovány P. Havlíčkem (Macháček et al. 2007). Ve vrtech byly zachyceny pannonské jíly vídeňské pánve překryté pozdně pleistocenními a holocenními písky a písčitými štěrky (s bází v hloubce 8,1 m) uložené v posledních 22400 letech (Havlíček 2004). Tyto jsou dále překryty šedo-černými písčito a jílovito prachovými povodňovými hlínami s bází v hloubce 1,7 m (Havlíček 2004) nebo jílovitými písky a písčitými jíly v hloubce až 6,6m (Doláková et al. 2010). Publikovaná radiokarbonová data z okolní nivy (Havlíček 1999: 3720 $\pm 60 \mathrm{BP}, 2619 \pm 60 \mathrm{BP}, 3180 \pm 330 \mathrm{BP}$ a Doláková et al. 2010: $8240 \pm 70$ BP cal BP a $7350 \pm 50$ cal BP) datují agradaci nivy do středního až pozdního holocénu.

Uvnitř hradiště Pohansko byla sedimentologickými a palynologickými metodami prokázána existence slepého ramene. Sedimenty klasifikované jako povodňové jíly byly zachyceny v rozmezí hloubek $1,7-0,10 \mathrm{~m}$ v kopané sondě S3 (Macháček et al. 2007). Z této sondy byly datovány 2 vzorky. První, z hloubky 1,27 m: $7830 \pm 60$ BP (7 050-6 450 cal BC), prokázal stáŕí spodního atlantiku (Firbas 1949) - odpovídající neolitu. Druhý, v hloubce 0,4 m: $2210 \pm 30$ BP (380-190 cal BC), odpovídal spodnímu subatlantiku - době železné. Další vzorek, který byl datován do hallstattu $2560 \pm 50$ years BP $(820-520 \mathrm{cal}$ $\mathrm{BC}$ ), pocházel z výplně archeologického objektu O1 (Doláková et al. 2010).

\section{Archeologie}

Archeologický výzkum navazoval prímo na sondu. Raně středověké osídlení dosahovalo až k okraji současného hrúdu. Jde o soustavu jak zahloubených, tak i na původním, raně středověkém povrchu postavených objektů. Podle předběžného určení archeologického materiálu byl tento prostor využíván již od 6 . století - pece, obilnice a potom také $\mathrm{v} 9$. a na počátku 10. století - zahloubené objekty neznámé funkce a část kostrového hrobu. Přímo v místě, kde na archeologický výzkum navazovala geologická sonda, se na hraně hrúdu nacházelo topeniště, zřejmě pyrotechnologického zařízení, které se již sesunovalo dolů po svahu. Vzhledem $k$ této situaci předpokládáme, že k erozi hrúdu a likvidaci dalších archeologických objektů došlo až po opuštění sídliště v 10. století.

\section{Metody}

Pro rekonstrukci komplikovaného vývoje nivy je nutné zkombinovat více metod. Základní metodou je terénní dokumentace a odběr vzorků sedimentu, které jsou doplněny metodami dálkového průzkumu a geofyziky.

Pro studium geomorfologie byl využit digitální model reliéfu, který byl vytvořen $\mathrm{z}$ dat digitálního výškopisu České republiky. Byla použita datová vrstva ground, která byla pomocí interpolace funkcí natural neighbour zpracována do rastru o rozlišení $1 \mathrm{~m}$. Použitá vizualizace byla vytvořena kombinací částečně průhledného digitálního modelu reliéfu se stínovaným modelem

Tab. 1: Electric resistivity tomography (ERT), měřené na dvou profilech.

Tab. 1: Electric resistivity tomography (ERT), 2 profiles.

\begin{tabular}{|c|c|c|c|c|c|}
\hline profile & $\begin{array}{c}\text { lenghth } \\
{[\mathbf{m}]}\end{array}$ & $\begin{array}{c}\text { electrode } \\
\text { spacing } \\
{[\mathbf{m}]}\end{array}$ & $\begin{array}{c}\text { electrode } \\
\text { configuration }\end{array}$ & $\begin{array}{c}\text { number of } \\
\text { iteration }\end{array}$ & $\begin{array}{c}\text { RMS } \\
{[\%]}\end{array}$ \\
\hline $\mathbf{1 - 1}^{\star}$ & 71 & 1 & $\begin{array}{c}\text { Wenner- } \\
\text { Schlumberger }\end{array}$ & 5 & 0.69 \\
\hline $\mathbf{2 - 2}^{`}$ & 56 & 1 & $\begin{array}{c}\text { Wenner- } \\
\text { Schlumberger }\end{array}$ & 5 & 0.77 \\
\hline
\end{tabular}




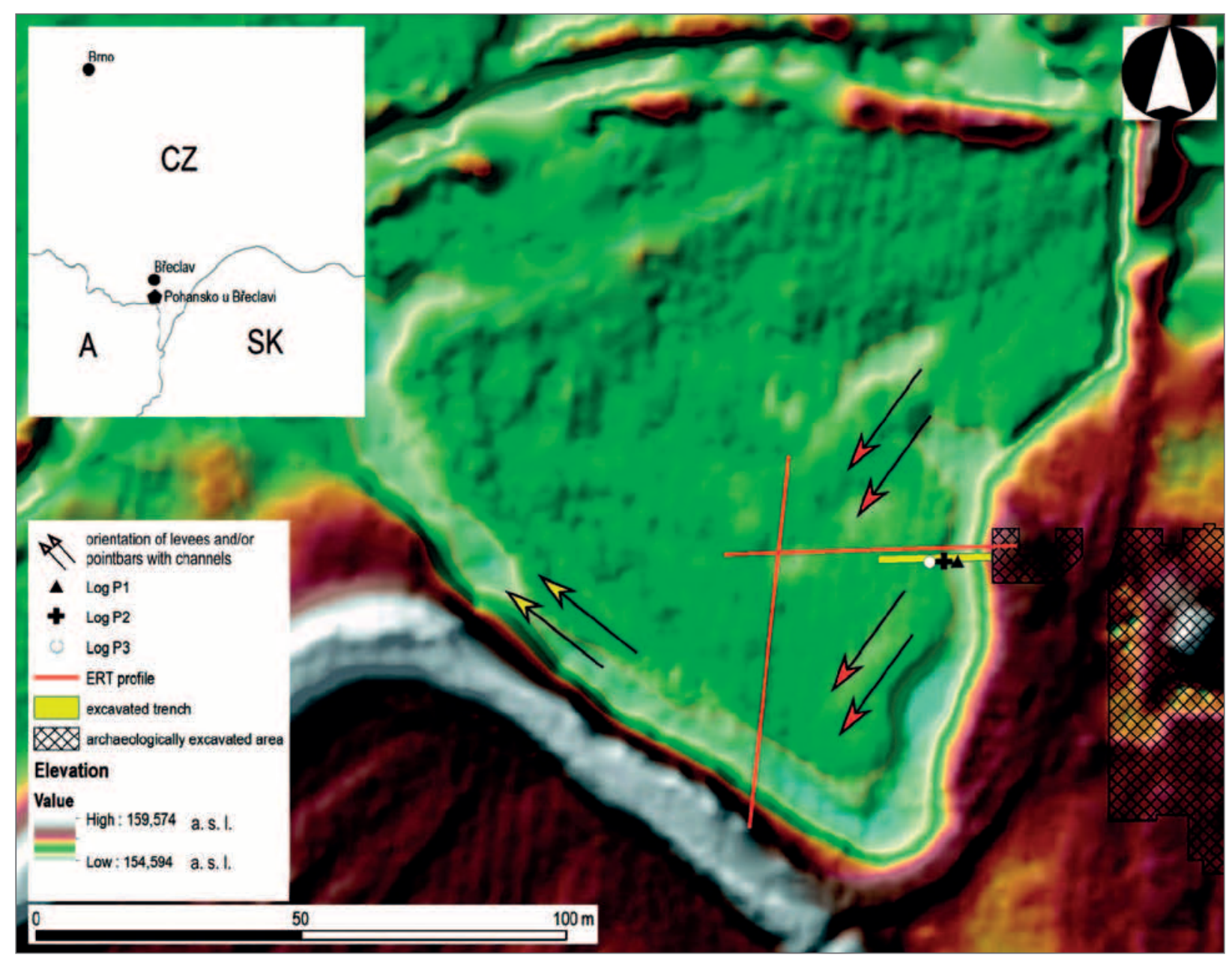

Obr. 1: Digitální model reliéfu (data Lidar) s vyznačenou pozicí bagrované sondy a pozicí dokumentačních a odběrových bodů. Orientace a pozice šipek indikuje valy a/nebo jesepy a kanály patrné na digitálním modelu reliéfu.

Fig. 1: Digital elevation model (Lidar) with position of trench and positions of sampling. Arrows orientation and position indicate levees and/or pointbars with channels visible at digital elevation model.

vytvořeným standardním nastavením v softwaru ArcGIS v dvojnásobném převýšení.

\section{Geofyzika (ERT, DEMP)}

ERT (Electrical resistivity tomography): Metodou ERT byly měřeny dva profily (tab. 1). K měření byl použit př́stroj ARES (GF Instruments, s.r.o., Czech Republic) a sekce multielektrodového kabelu. Naměřená data byla inverzně přepočítána v programu Res2Dinv (Geotomo
Inc., Malaysia) a interpolována zpracována v systému Surfer (Golden Software LLC, USA).

DEMP (dipole electromagnetic profiling): Mapa anomálií vodivosti byla měřena pomocí přístroje CMD-4 (GF Instruments, s.r.o., Czech Republic) při zapojení v kontinuálním módu a s použitím GPS jednotky pro zjištění pozice každého měřeného bodu. Celkem byla proměřena plocha $54000 \mathrm{~m}^{2}$. Maximální hloubkový dosah prŕstroje byl nastaven na $3 \mathrm{~m}$ při rychlosti měření

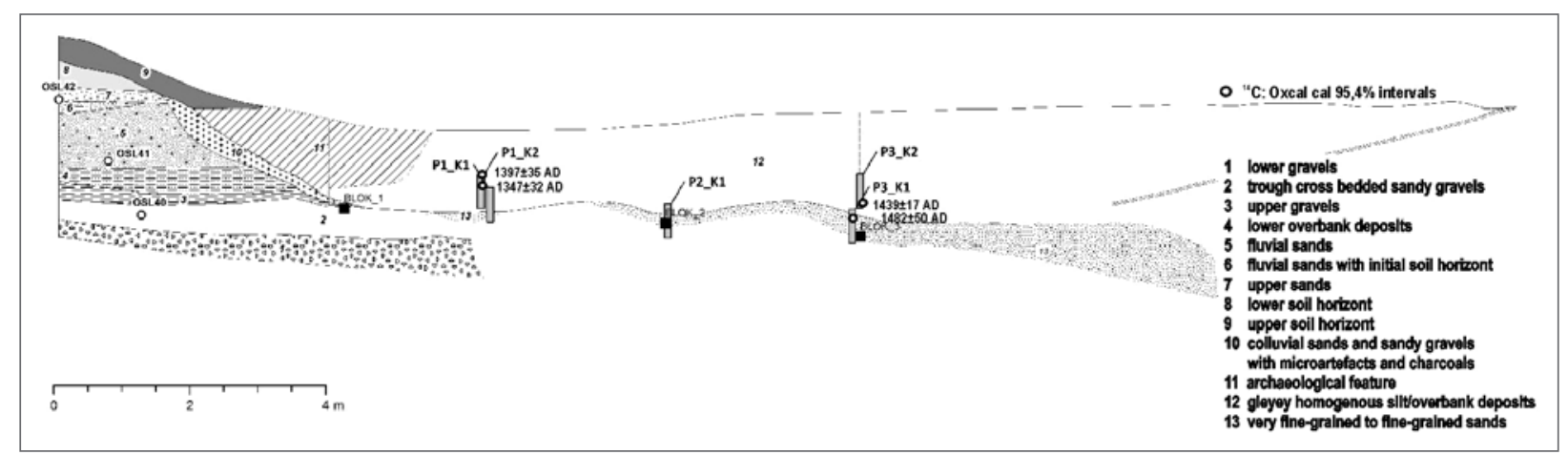

Obr. 2: Litologický profil - mozaika zkoumanými sedimenty.

Fig. 2: Lithological profile - mosaic of studied sediments. 
Tab. 2: ${ }^{14} \mathrm{C}$ datování (Poznan radiocarbon Laboratory). Tab. 2: ${ }^{14} \mathrm{C}$ dating (Poznan radiocarbon Laboratory).

\begin{tabular}{|c|c|c|c|c|c|}
\hline Sample & $\begin{array}{c}\text { Depth under } \\
\text { surface }[\mathbf{c m}]\end{array}$ & Lab ID & ${ }^{14}$ C Age & $\begin{array}{c}\text { Oxcal cal } \\
\mathbf{9 5 . 4 \%} \\
\text { intervals }\end{array}$ & $\begin{array}{c}\boldsymbol{\mu} \pm \boldsymbol{\sigma} \text { cal } \\
\text { (Oxcal) }\end{array}$ \\
\hline P-1/2016-1 & 94 & Poz-87746 & $415 \pm 30 \mathrm{BP}$ & $1320-1440$ & $1397 \pm 35$ \\
\hline P-1/2016-2 & 122 & Poz-87747 & $530 \pm 30 \mathrm{BP}$ & $1298-1410$ & $1347 \pm 32$ \\
\hline P-3/2016-1 & 165 & Poz-87748 & $595 \pm 30 \mathrm{BP}$ & $1412-1468$ & $1439 \pm 17$ \\
\hline P-3/2016-2 & 186 & Poz-87749 & $460 \pm 30 \mathrm{BP}$ & $1429-1619$ & $1482 \pm 50$ \\
\hline
\end{tabular}

* Pozn. $0.5 \mathrm{mgC}$

každého bodu 0,3 s. Výsledná data jsou interpolována a zobrazena pomocí softwaru ArcMap (Esri, USA).

\section{Palynologie}

Pro palynologické účely byly odebrány 3 kontinuální profily, celkem v 6 zatloukaných krabicích (P1_K1, P1_K2 a P3_K1, P3_K2 - viz obr. 1). Pro palynologické studium byly vzorky laboratorně zpracovány metodou macerace $(\mathrm{HCl}, \mathrm{HF}, \mathrm{KOH})$ a acetolýzy $\left[\mathrm{H}_{2} \mathrm{SO}_{4}+\left(\mathrm{CH}_{3} \mathrm{CO}\right)_{2} \mathrm{O}\right]$. $\mathrm{Z}$ důvodů zkoncentrování obsahu palynomorf bylo využito těžké kapaliny $\mathrm{ZnCl}_{2}$. Determinace palynomorf byla prováděna optickým mikroskopem Nikon Alphaphot 2, zejména podle prací Beug (2004) a Reille (1999). Pylový diagram byl zpracován programem POLPAL (Walanus, Nalepka 1999).

Z prostoru dokumentačních bodů P1 (v masivních siltech overbank) a P3 (dno koryta) byly vybrány 4 vzorky, které byly datovány metodou ${ }^{14} \mathrm{C}$ (Poznań Radiocarbon Laboratory) (tab. 2, obr. 2, 3). Datování bylo provedeno metodou ${ }^{14} \mathrm{C}$ AMS (Poznań Radiocarbon Laboratory). Kalibrace dat byla provedena v programu OxCal 4.3 (Bronk
Ramsey 2009) podle kalibrační křivky IntCal 13 (Reimer et al. 2013).

\section{Výsledky Geomorfologie a geofyzika}

Data dálkového průzkumu umožnila detailní dálkový průzkum reliéfu. Okolí elevace s archeologickou lokalitou Pohansko je tvořeno sériemi valů a/ nebo jesepů a koryt, jejichž morfologie se projevuje na digitálním modelu reliéfu (obr. 1). Z morfologie povrchu je patrné, že ve zkoumaném prostoru existuje starší generace valů nebo jesepů s koryty (obr. 1: červené šipky), která je erodována mladší generací (obr. 1: žluté šipky) valů nebo jesepů s koryty. Zkoumána byla soustava fluviálních valů a/nebo jesepů a koryt. Plošné geofyzikální měření metodou DEMP dokládá existenci zaniklého koryta v hloubce do tří metrů (obr. 4). Stavbu detailněji odráží interpolovaný výsledek profilového ERT měření, které ukazuje př́tomnost koryta a řady jesepů (profil 2-2'), případně přítomnost soustavy dvou koryt a více jesepů (profil 1-1').

\section{Stratigrafie a datování}

Za účelem př́mého výzkumu stratigrafie byl zkoumán strojově odkrytý profil vedoucí z okraje hrúdu směrem do prostoru domnělého koryta (obr. 1). Ten zachytil krom sekvence štěrků, štěrkopísků a písků vlastního hrúdu (obr. 2: vrstvy 1-7, obr. 3: Nehyba et al. 2018) také stratigraficky mladší jemně zrnité písky (obr. 2 a 3 , vrstva 13 v hloubce cca 1,5 až $2,5 \mathrm{~m}$ ) překryté masivními
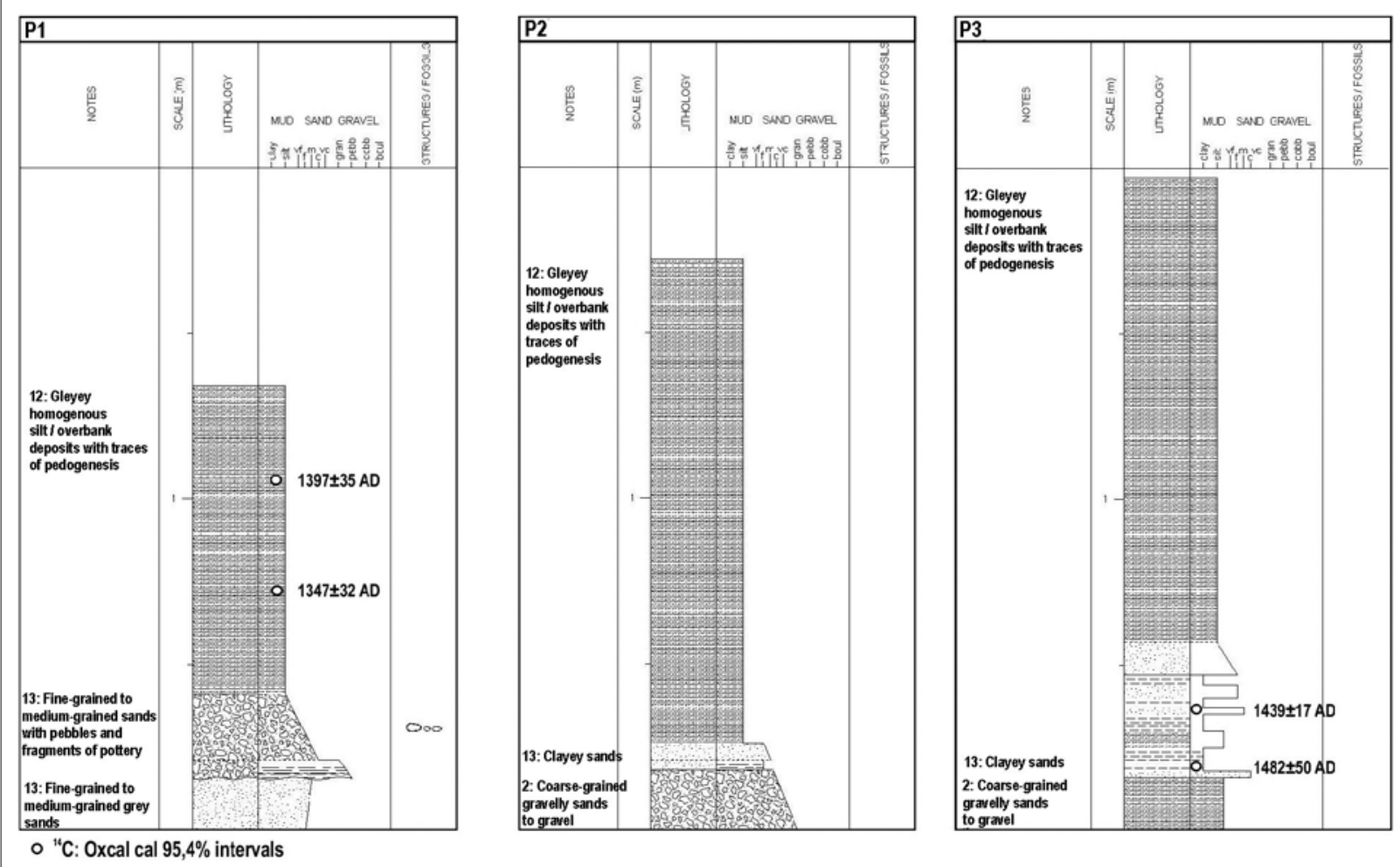

Obr. 3: Sedimentologický popis v dokumentačních bodech a pozice vzorků datovaných radiokarbonovou metodou. Fig 3: Sedimentological description of logs and position of samples dated by radiocarbon method. 


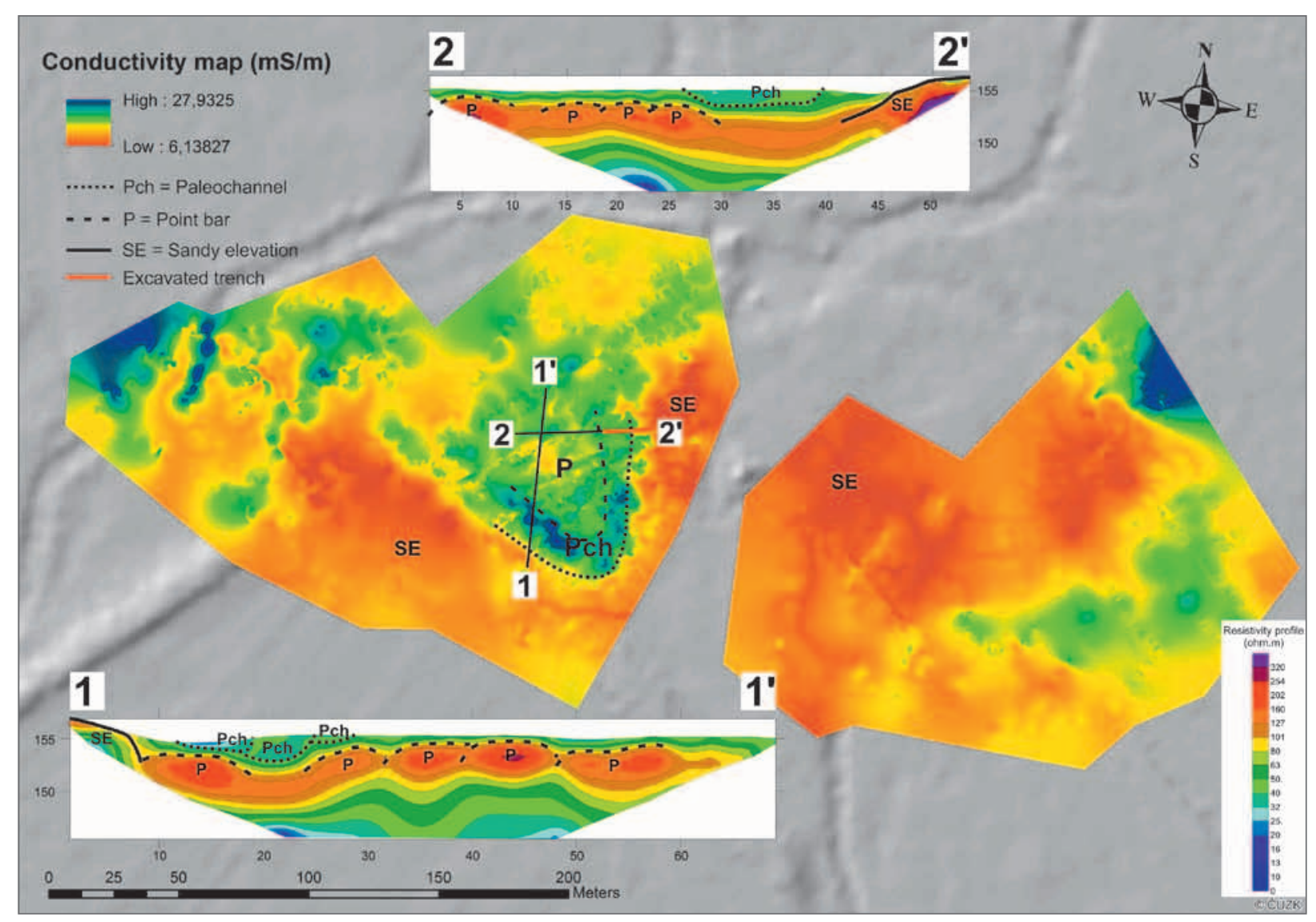

Obr. 4: Mapa anomálií vodivosti, DEMP (dipole electromagnetic profiling) dokládající existenci valů a/nebo jesepů a zaniklého koryta.

Fig. 4: Map of conductivity anomalies, DEMP (dipole electromagnetic profiling), which give evidence of levees and/or pointbars with paleochannel.

rezavě smouhovanými silty (obr. 2 a 3: vrstva 12, mocnost 1 až $2 \mathrm{~m}$ ). Vedle jsou na vlastním hrúdu vyvinuty dva půdní horizonty, z nichž jeden je stratigrafický starší a odpovídá velkomoravské kulturní vrstvě a svrchnější odpovídá recentnímu A horizontu. Na rozhraní hrúdu a masivních siltů byla také zachycena vrstva pískových až štěrkopískových splachů obsahujících fragmenty raně středověkých artefaktů (úlomky keramiky a mazanice) a na ně nasedající archeologický objekt (výkop) bez jasně datovatelného materiálu.

Zkoumaná sekvence byla podrobněji popsána v dokumentačních bodech P1, P2 a P3 (obr. 3).

Podle výsledků radiokarbonového datování můžeme klást aktivní fáze koryta do 14.-16. století a jeho následné zanesení do 16. století.

\section{Palynologie}

Vzhledem k totožnému stáří datovaných profilů byly pro palynologické vyhodnocení vybrány profily P1 a P2. $\mathrm{Z}$ těchto profilů bylo vyhodnoceno 14 vzorků. Pět $\mathrm{z}$ nich obsahovalo velmi nízký počet palynomorf, a nebyly proto vhodné pro interpretaci palynospekter. Semikvantitativní zpracování ve formě pylového diagramu bylo provedeno celkem na 9 vzorcích, které obsahovaly minimálně 100 determinovaných pylových zrn a spor $(64,70,76,82,88$, $94,106,118,123,128,134,146,158,164 \mathrm{~cm}$ od povrchu viz obr. 5).
Ze studovaných vzorků obou profilů lze interpretovat mozaikovitou krajinu tvořenou zalesněnými plochami mezofilních a lužních porostů a otevřených ploch. Dřeviny tvoří 25-48 \% z celkového složení pylového spektra. Porosty mezofilních lesů byly převážně tvořeny dubem (Quercus, 7-20\%) s menší příměsí javoru (Acer), habru (Carpinus) a lípy (Tilia). Poměrně pravidelně byla v profilech nalézána pylová zrna ochmetu (Loranthus), který v nejteplejších oblastech parazituje na dubech. $\mathrm{V}$ nízkých množstvích se téměř ve všech vzorcích vyskytoval ořešák, který není na našem území původní rostlinou. Na Pohansku byl nalézán i v palynospektrech ze sedimentů z období starohradištního a velkomoravského (Doláková et al. 2010; Macháček et al. 2007). Jeho nálezy jsou známé i z dalšího, nedalekého velkomoravského centra Mikulčice (Opravil 1998). Lužní lesy jsou zastoupeny porosty tvrdého (Alnus, Ulmus) i měkkého luhu (Salix, Fraxinus, Populus). V pylových diagramech jsou patrné postupné (periodické) změny vzájemného poměru mezofilních doubrav a lužních porostů. Tento jev indikuje změnu humidity substrátu spojenou s posouváním říčních ramen. Ve vzorku $\mathrm{z}$ hloubky $158 \mathrm{~cm}$ tvoří vrby (Salix) rostoucí na okrajích vodních toků až $14 \%$ vegetace. $\mathrm{V}$ několika vzorcích byl zjištěn výskyt zelené řasy rodu Pediastrum, která indikuje vodní prostředí. $\mathrm{Z}$ dalších dřevin byly přítomné bříza (Betula), borovice (Pinus) a velmi ojediněle buk (Fagus), jedle (Abies) 


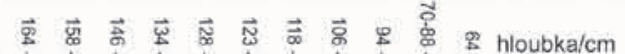

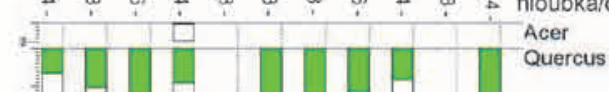

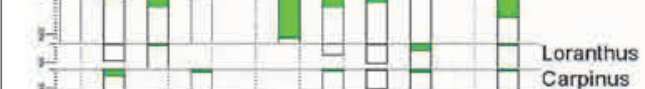

G G a

, A

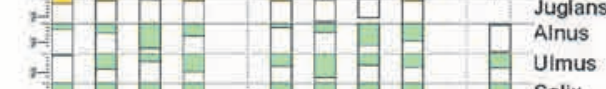

,H Halix
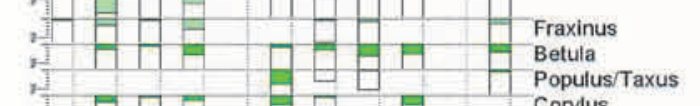

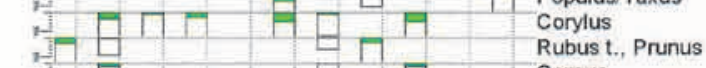

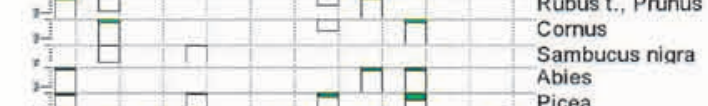

2-

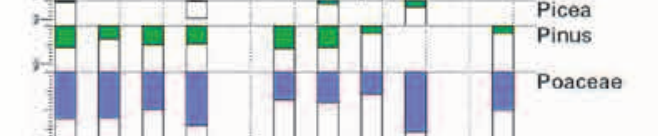

H. $=-1$ Chenopodiaceae

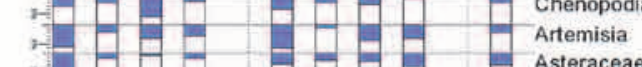

2- HF HA Asteraceae Liguliforae

Astraceae Tubiflorae
Cirsium /Carduus/Arctium
Brassicaceae

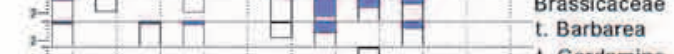

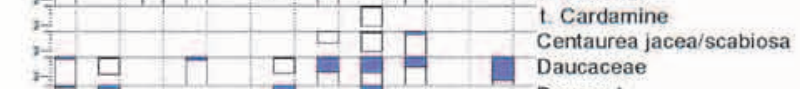

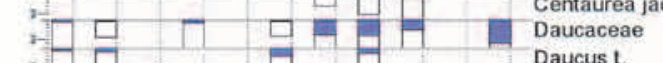

2H

2개

, 4 A

2근 $\square \Pi \square \square$ Vicia alba

Eranthis - talovin

:

:

Chelldonium
Lamiaceae

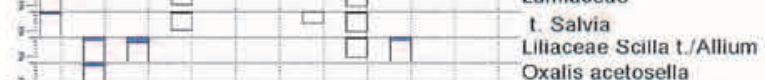

Dlantago majorime

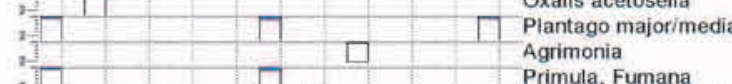

$\begin{array}{lll}\square & \square & \text { Pgrimula, Fumana } \\ 2 & & \text { Pulmonaria/Aquilegia }\end{array}$

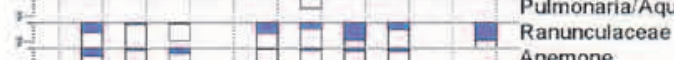

步

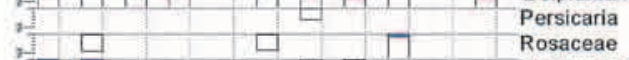

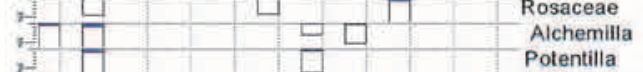

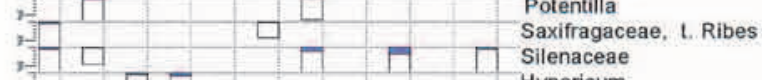

,

1. -

ITHA-

T $\square \square \Pi \quad \prod \begin{aligned} & \text { Caltha } \\ & \text { Oeanthe }\end{aligned}$

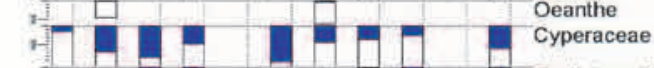

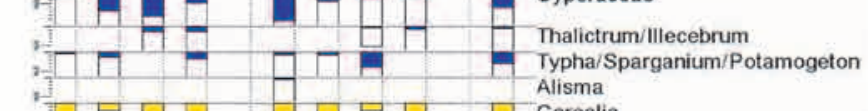

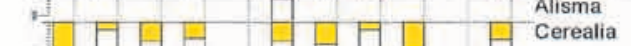

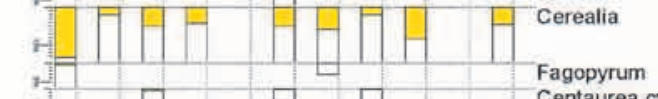

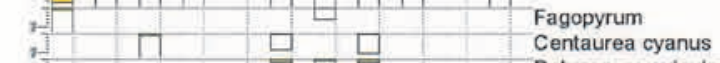

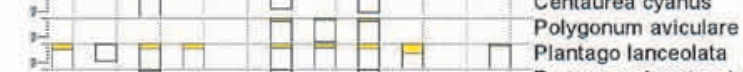

政

, 3 ,

口 7 Pteridium typ

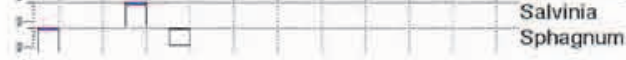

Obr. 5: Pylový diagram zkombinovaný z profilů P1a P2. Fig. 5: Pollen diagram combinated from P1 nd P2 profiles.

a smrk (Picea). V pylových spektrech byly rovněž zastoupeny křoviny rostoucí na okrajových cástech lesních ploch (Corylus, Sambucus, Cornus, Rubus). Otevřené plochy byly porostlé zejména travinami (Poaceae) a pestrým složením bylin jak mezofytních (Euphorbia, Galium, Geranium, Anemone, Alchemilla atd.), tak méně sušších stanoviš̀' (Cirsium, Centaurea scabiosa, Delphinium, Lotus, Artemisia). Hojné bylo zastoupení bylin rostoucích na zamokřených substrátech (Cyperaceae, Lythraceae, Caltha, Chrysosplenium). Rostliny vázané na zvýšený obsah dusíku byly př́tomné pravidelně, ale v nevýrazném množství (merlíkovité - Chenopodiaceae, kopřiva Urtica), které by poukazovalo na intenzívní nitrifikaci spojenou s lidskou aktivitou (pastva dobytka, hnojení půdy). Nicméně přitomné antropogenní indikátory jako obiloviny (cerealia) byly zaznamenány v celém profilu. Jejich nejvyšší množství spojené s největší mírou odlesnění bylo pozorováno v nejspodnějším vzorku $(164 \mathrm{~cm})$. Antropogenní plevele jako jsou chrpa modrák (Centaurea cyanus) či štovík kyselý (Rumex acetosa) byly zjištovány nahodile. $\mathrm{V}$ ojedinělých výskytech byla zaznamenána pohanka (Fagopyrum), která je na našem území pěstována od 12 . století.

Z pylových spekter lze odvodit, že v období zachyceném ve studovaných profilech (14.-16. století) nebylo bezprostř̌ední okolí sedimentačního prostoru př́lišs intenzivně zasažené zemědělskou aktivitou.

\section{Diskuze a závěr}

Digitální model reliéfu dokládá, že při S. okraji tzv. Severozápadního předhradí (hrúdu) vznikly nejspíše dvě generace fluviálních valů a/nebo jesepů s koryty. Geofyzikální měření doložilo existenci těchto těles pod současným povrchem. Odkryv zachytil především starší z nich. Jejich stratigrafická pozice dosvědčuje fázi, kdy aktivní koryto erodovalo okraj archeologické lokality. Předpoklad, že k erozi mohlo docházet těsně po zániku osídlení, nebo že zde existoval s tímto zánikem kauzální vztah, nebyl na zkoumaném výseku lokality potvrzen, protože datování sedimentů nejnižšího nivního stupně (soustava koryt erodujících hrúd a jejich výplně) odpovídá vrcholnému stř̌edověku. Sedimenty uložené v předchozích obdobích se tedy $\mathrm{v}$ tomto prostoru nedochovaly. Zjišsěná sekvence dokládá agradaci nivy ve 14.-16. století, což je v souladu $\mathrm{s}$ výsledky OSL a ${ }^{14} \mathrm{C}$ datování z nedalekých profilů (Petřík et al. $\mathrm{v}$ tisku). Zjištěný záznam umožňuje srovnání s dřive publikovaným vývojem $\mathrm{v}$ předchozích obdobích. 
V porovnání s palynospektry ze sedimentů období velkomoravského osídlení (Doláková et al. 2010), byla míra odlesnění a podíl antropogenních indikátorů znatelně nižší. Naopak pylové spektrum velmi dobře odpovídá raně novověkému profilu (Petř́k et al. v tisku) v rámci trench 2, situovanému $140 \mathrm{~m}$ jv. od zkoumaného profilu. Po zániku raně středověkého osídlení nebylo území soutoku kolonizováno ve vrcholném středověku. Naopak začátkem novověku zde byla zřízena obora (Miklín, Hradecký 2016) s extenzivním využitím krajiny a jen minimálním rozsahem obilných polí. Vegetace je velmi podobná současnému stavu od vrcholného středověku po současnost, včetně zastoupení druhově bohatých mezofilních luk až xerotermních stanovišt' (Roleček et al. 2015), které lze identifikovat v pylových spektrech.

Zajímavý je výskyt smrku, jedle a buku v analyzovaných vzorcích, které jsou vcelku časté v nížinných pylových profilech z povodí Moravy (Petr, Novák 2014; Novák et al. 2017) ve středním a mladším holocénu, ale ve vrcholném středověku a novověku výrazně ustupují. V oblasti soutoku je udáván sporadický přirozený výskyt smrku (www.pladias.cz). Naopak jedle a buk zjištěné v pylových profilech z Pohanska (Doláková et al. 2010;
Petř́ik et al. v tisku) dnes přirozeně na soutoku nerostou, nejbližší přirozený výskyt buku je v hodonínské doubravě přibližně $30 \mathrm{~km}$ severovýchodně od Pohanska a v prrípadě jedle je její přirozený výskyt v Bílých Karpatech. Jedle byla pravděpodobně $\mathrm{v}$ nížině častá jako součást pastevních lesů (Kozáková et al. 2014), změnou managementu lesů ve vrcholném středověku a novověku vymizela a stala se součástí lesů ve středních a vyšších polohách, podobně jako buk. Naopak smrk je edaficky vázaný na vlhká stanovišš̌, kde se může vyskytovat v azonálních společenstvech podél vodních toků i v nížině (Opravil 1983; Novák et al. 2017). Zastoupení ostatních dřevin odpovídá dnešní vegetaci Pohanska a jeho stanovištní diverzitě.

\section{Poděkování}

Článek vznikl za podpory projektu GAČR 16-15678S - Vývoj interakce prírodního prostředí a subsistenční strategie raně středověké společnosti (Development of interaction of the environment and the subsistent strategy of early medieval society). Děkujeme rovněž recenzentưm za cenné připomínky, které dopomohly zlepšit kvalitu a srozumitelnost článku.

\section{Literatura}

Beug, H. J. (2004). Leitfaden der pollenbestimmung für Mitteleuropa und angrenzende Gebiete. - Verlag Dr. Fridrich Pfeil; München. Boardman, J., Bell, M. (1992). Past and present soil erosion: linking archaeology and geomorphology. - In: Bell, M., Boardman, J. (eds): Past and Present Soil Erosion, Oxbow Monograph 22, Oxbow Books, Oxford, 1-8.

Bronk Ramsey, C. (2009). Dealing with Outliers and Offsets in Radiocarbon Dating. - Radiocarbon, 51, 3, 1023-1045. https://doi. org/10.1017/S0033822200034093

Castelltort, S., Van den Driessche, J. (2003). How plausible are high-frequency sediment supply-driven cycles in the stratigraphic record? - Sedimentary geology, 157, 1-2, 3-13. https://doi.org/10.1016/S0037-0738(03)00066-6

Doláková, N., Roszková, A., Přichystal, A. (2010). Palynology and natural environment in the Pannonian to Holocene sediments of the Early Medieval centre Pohansko near Břeclav (Czech Republic). - Journal of Archaeological Science, 37, 10, $2538-2550$. https://doi.org/10.1016/j.jas.2010.05.014

Dresler, P., Macháček, J. (2008). The hinterland of an Early Mediaeval centre at Pohansko near Břeclav. - In: Poláček, L. (ed.): Das Wirtschäftliche Hinterland Der Frühmittelalterlichen Zentren, Spisy Archeologického ústavu AV ČR Brno, 31, Archeologický ústav Brno.

Enters, D., Dörfler, W., Zolitschka, B. (2008). Historical soil erosion and land-use change during the last two millennia recorded in lake sediments of Frickenhauser See, northern Bavaria, central Germany. - Holocene, 18, 2, 243-254. https://doi. org/10.1177/0959683607086762

Firbas, F. (1949). Die spät- und nacheiszeitliche Waldgeschichte Mitteleuropas nördlich der Alpen. - I. Allgemeine Waldgeschichte. -480 s. Jena.

Havlíček, P. (1999). Die geologische Verhältnisse in der Umgebung der Siedlungsagglomerationen der groß- mährischen Machtzentren Mikulčice und Staré Město - Uherské Hradiště. - In: Poláček, L., Dvorská, J. (eds): Probleme der mitteleuropäischen Dendrochronologie und naturwissenschaftliche Beiträge zur Talaue der March. Internationale Tagungnen in Mikulčice V, 181-198. Brno.

Havlíček, P. (2004). Geologie soutokové oblasti Dyje s Moravou. - In: Hrib, M., Kordiovský, E. (eds): Lužní les v Dyjsko-moravské nivě, 11-19. Břeclav.

Havlíček, P., Smolíková, L. (2002). Subfosilní polygenetická pseudočernozem v navátých píscích při soutoku Dyje s Moravou (Barvínkův hrúd), Jižní Morava. - Geologické výzkumy na Moravě a ve Slezsku v roce 2001, 9, 2-3.

Havlíček, P., Bř́izová, E., Hošek, J., Sidorinová, T. (2016). Geologický výzkum na soutoku Dyje, Kyjovky a Moravy. - Zprávy o geologických výzkumech, 49, 225-232.

Kalicki, T. (2006). Zapis zmian klimatu oraz działalności człowieka i ich rola w holoceńskiej ewolucji dolin środkowoeuropejskich. - Prace Geograficzne IGiPZ PAN 2042006.

Kozáková, R., Pokorný, P., Mařík, J., Čulíková, V., Boháčová, I., Pokorná, A. (2014). Early to high medieval colonization and alluvial landscape transformation of the Labe valley (Czech Republic): evaluation of archaeological, pollen and macrofossil evidence. - Vegetation History and Archaeobotany, 23, 6, 701-718. https://doi.org/10.1007/s00334-014-0447-1 
Leopold, L. B., Wolman, M. G. (1957). River channel patterns-braided, meandering and straight. - U.S. Geological Survey Professional Paper 282B, 1957, 39-85. https://doi.org/10.3133/pp282B

Macháček, J., Doláková, N., Dresler, P., Havlíček, P., Hladilová, Š., Přichystal, A., Roszková, A., Smolíková, L. (2007). Raně středověké centrum Na Pohansku u Břeclavi a jeho př́rodní prostředí. - Archeologické rozhledy LIX, 2, 278-314.

Mazuch, M. (2012). Doklady novověkých aktivit v prostoru zaniklého raně středověkého mocenského centra Mikulčice - Valy. - Jižní Morava, 48/2012, 7-45.

Miklín, J., Hradecký, J. (2016). Confluence of the Morava and Dyje Rivers: a century of landscape changes in maps. - Journal of Maps, 12, 630-638. https://doi.org/10.1080/17445647.2015.1068714

Nehyba, S., Dvořáková, M., Doláková, N., Dresler, P. (2018). Kvartérní sedimenty na Severním předhradí lokality Pohansko u Břeclavi. - Geologické výzkumy na Moravě a ve Slezsku, 25, 1-2, 34-40. https://doi.org/10.5817/GVMS2018-1-2-34

Novák, J., Abraham, V., Kočár, P., Petr, L., Kočárová, R., Nováková, K., Houfková, P., Jankovská, V. Vaněček, Z. (2017). Middleand upper-Holocene woodland history in central Moravia (Czech Republic) reveals biases of pollen and anthracological analysis. - Holocene, 27, 3, 1, 349-360. https://doi.org/10.1177/0959683616660166

Opravil, E. (1983). Údolní niva v době hradištní. (ČSSR - povodí Moravy a Poodří). - Academia, Praha.

Opravil, E. (1998). Zusammenfassende Ubersicht der Ergebnisse von Analysen der Makroreste pflanzlicher Herkunft aus Mikulčice. - Studien zum Burgwall von Mikulčice, 3, 327-353.

Petr, L., Novák, J. (2014). High vegetation and environmental diversity during the Late Glacial and Early Holocene on the example of lowlands in the Czech Republic. - Biologia (Poland), 69, 7, 847-862.

Petřík, J., Petr L., Šabatová, K., Doláková, N., Lukšíková, H., Dohnalová, A., Koptíková, L., Blaško, D. (2015). Reflections of Prehistoric and Medieval human activities in floodplain deposits of the Unanovka Stream, South Moravia, Czech Republic. - Zeitschrift für Geomorphologie, 59, 3, 393-412. https://doi.org/10.1127/zfg/2015/0167

Petř́́k, J., Petr, L., Adameková, K., Prištáková, M., Potůčková, A., Lendáková, Z., Frączek, M., Dresler, P., Macháček, J., Kalicki, T., Lisá, L. (v tisku). Disruption in an alluvial landscape: Settlement and environment dynamics on the alluvium of the river Dyje at the Pohansko archaeological site (Czech Republic). - Quaternary International. https://doi.org/10.1016/j. quaint.2018.04.013

Reille, M. (1995). Pollen et Spores d'Europe et d'Afrique du nord. - Laboratoire de Botanique Historique et Palynologie, Marseille. Reimer, P. J., Bard, E., Bayliss, A., Beck, J. W., Blackwell, P. G., Bronk Ramsey, C., Buck, C. E., Cheng, H., Edwards, R. L., Friedrich, M., Grootes, P. M., Guilderson, T. P., Haflidason, H. Hajdas, I., Hatté, C., Heaton, T. J., Hoffmann, D. L., Hogg, A. G., Hughen, K. A., Kaiser, K. F., Kromer, B., Manning, S. W., Niu, M., Reimer, R. W., Richards, D. A., Scott, E. M., Southon, J. R., Staff, R. A., Turney, C. S. M., van der Plicht, J. (2013). IntCal13 and Marine13 Radiocarbon Age Calibration Curves 0-50 000 Years cal BP.

Roleček, J., Hájek, M., Karlík, P., Novák, J. (2015). Reliktní vegetace na mezických stanovištích, Relict vegetation on mesic sites. - Zprávy České botanické společnosti, 50, 201-245.

Rulf, J. (1994). Pravěké osídlení stř̌ední Evropy a niva. - In: Beneš, J., Brůna, V. (eds): Archeologie a Krajinná Ekologie, 1994, Nadace Projekt Sever, 54-55. Most.

Schneeweiss, J., Schatz, T. (2014). The impact of landscape change on the significance of political centres along the lower Elbe River in the $10^{\text {th }}$ century A.D. - Quaternary International, 324, 20-33. https://doi.org/10.1016/j.quaint.2013.12.059

Starkel, L., Gebica, J., Superson, P. (2007). Last Glacial - Interglacial cycle in the evolution of river valleys in southern and central Poland. - Quaternary Science Reviews, 26, 22-24, 2924-2936. https://doi.org/10.1016/j.quascirev.2006.01.038

Walanus, A., Nalepka, D. (1999). POLPAL. Program for counting pollen grains, diagrams plotting and numerical analysis. - Acta Paleobotanica, 2, 659-661. http://www.pladias.cz, 15. 5. 2018

Editor: Martin Ivanov

Doporučená citace článku: Petř́k, J., Doláková, N., Nehyba, S., Lend'áková, Z., Prištáková, M., Adameková, K., Petr, L., Dresler, P., Macháček, J. (2018). Zaniklý meandr u Severního předhradí archeologické lokality Pohansko u Břeclavi. - Geologické výzkumy na Moravě a ve Slezsku, 25, 1-2, 41-48. 